\title{
Masses of the marine insect Pontomyia oceana at Ningaloo Reef, Western Australia
}

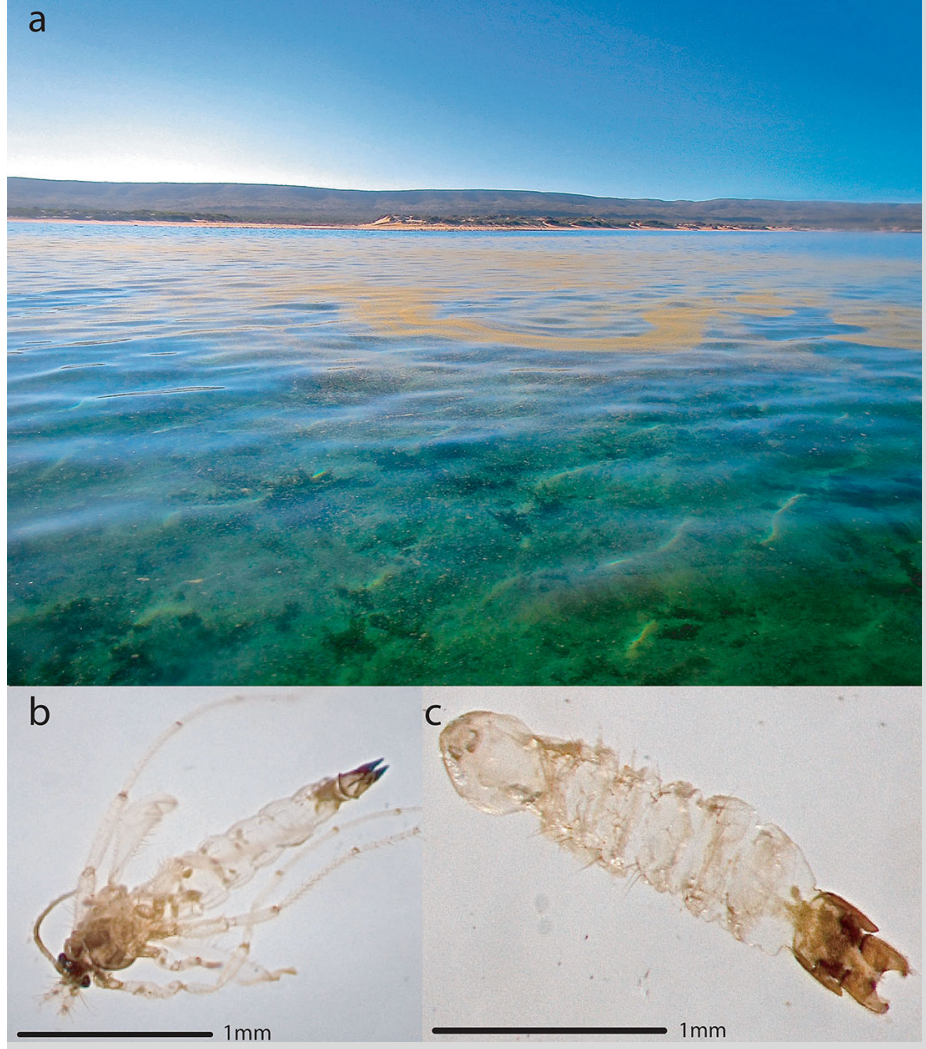

Fig. 1 a Pontomyia oceana masses at Turquoise Bay, Ningaloo Reef. b Male, and c female specimen of $P$. oceana
Pontomyia, an exclusively marine genus of flightless chironomid insect, are rarely observed on the ocean surface. Only three genetically distinct species from the genus are described: $P$. natans, $P$. pacifica, and $P$. oceana, of which one, Pontomyia oceana, has been previously recorded at only three locations [Palau (males only), Heron Island (Queensland, Australia), and Taiwan (Huang et al. 2014)]. Upon maturation, $P$. oceana synchronously emerge at the water surface to reproduce in one of the shortest adult life spans (1-3 h) among all insects (Soong et al. 1999).

Here, we report an observation of $P$. oceana in the Indian Ocean. Pontomyia oceana were observed in masses as extensive ( $100 \mathrm{~m}$ wide) orange patches on the water surface (Fig. 1) in the lagoon surrounding Turquoise Bay $\left(22^{\circ} 02^{\prime} \mathrm{S}, 113^{\circ} 54^{\prime} \mathrm{E}\right)$ between 0800 and $0900 \mathrm{hrs}$ on March 10,$2016 ; 1$ day after the new moon. The masses were observed across $>2 \mathrm{~km}$ along the coast, $\sim 500 \mathrm{~m}$ from the shore, in water 2-3 m deep, and in an area where seagrass and algal species previously found to be associated with the insects-both Halophila ovalis and Sargassum spp.- -are common (Huang et al. 2014). High tide occurred at $1043 \mathrm{hrs}$ on $10 \mathrm{March}$, wind was negligible, and the water temperature was $26^{\circ} \mathrm{C}$. Specimens were collected that showed markedly dimorphic males and females, which were identified through species keys (Cheng and Hashimoto 1978) and verified through DNA sequencing to be genetically closest to $P$. oceana specimens from Taiwan.

These marine insect masses were similar in scale to the masses of coral spawn seen along the Ningaloo Reef in coral spawning season and may represent a previously unrecognized food source for reef inhabitants. Our observation is an important documentation of an expansion of the previously known distribution of P. oceana.

Acknowledgments Many thanks to D. Huang for conducting the DNA sequencing for the specimens. Thanks to M. Vanderklift, R. Babcock, O. Berry, and D. Thomson for their enthusiasm and support.

\section{References}

Cheng L, Hashimoto H (1978) The marine midge Pontomyia (Chironomidae) with a description of females of $P$. oceana Tokunaga. Syst Entomol 3:189-196

Huang D, Cranston PS, Cheng L (2014) A complete species phylogeny of the marine midge Pontomyia (Diptera: Chironomidae) reveals a cosmopolitan species and a new synonym. Invertebr Syst 28:277-286

Soong K, Chen G-F, Cao J-R (1999) Life history studies of the flightless marine midges Pontomyia spp. (Diptera: Chironomiade). Zool Stud 38:466-473

C. Bessey · A. K. Cresswell ( $₫)$

CSIRO Oceans and Atmosphere, Wembley, WA 6014, Australia

e-mail: Anna.Cresswell@csiro.au

C. Bessey · A. K. Cresswell

University of Western Australia, Crawley, WA 6009, Australia 